\title{
Flood modeling using WMS model for determining peak flood discharge in southwest Iran case study: Simili basin in Khuzestan Province
}

\author{
Yaser Hoseini $^{1} \cdot$ Arash Azari $^{2} \cdot$ Alireza Pilpayeh $^{3}$
}

Received: 22 January 2016/Accepted: 3 October 2016/Published online: 12 October 2016

(c) The Author(s) 2016. This article is published with open access at Springerlink.com

\begin{abstract}
It is of high importance to determine the flood discharge of different basins, in studies on water resources. However, it is necessary to use new models to determine flood hydrograph parameters. Therefore, it will be beneficial to conduct studies to calibrate the models, keeping in mind the local conditions of different regions. Therefore, this study was carried out to determine the peak flood discharge of a basin located in Southwest Iran, using the TR-20, TR55, and HEC-1 methods of the WMS model (watershed modeling system). The obtained results were compared with empirical values, as well as those of the soil conservation service (SCS) approach. Based on the results obtained, the TR55 method of the WMS model recorded the highest agreement with empirical values in Southwest Iran.
\end{abstract}

Keywords Peak flood discharge $\cdot$ Flood routing $\cdot$ WMS

Yaser Hoseini

yaser_hoseini@ymail.com

Arash Azari

arashazari.ir@gmail.com

Alireza Pilpayeh

a.pilpayeh54@yahoo.com

1 Moghan College of Agriculture and Natural Resources, University of Mohaghegh Ardabili, Ardabil, Iran

2 Department of Water Engineering, Razi University, Kermanshah, Iran

3 Department of Water Science and Engineering, Parsabad Branch, Islamic Azad University, Parsabad, Iran

\section{Introduction}

Flood is a natural phenomenon, which threatens the life and properties of a large number of people all over the world, on a yearly basis. Flood discharge is of high importance in studies regarding water resource exploitation, flood control, construction of dams, basin management, and hydrologic studies. Therefore, the accuracy of these studies and the safety of waterworks and water structures depend on the methods of studies to a large extent. It is impossible to manage water resources in basins without accurate determination of the peak flood discharge (Bhadra et al. 2008; USBR 1998). The advances in flood estimation techniques have made it possible to use rainfallrunoff models to assess the hydrographic properties of flood in watersheds and decrease the risks of flood (Yonatan et al. 2009).

Non-accurate determination of rainfall and the costly process of collecting hydrologic data and statistics are among the difficulties of estimating flood properties in basins (Lopez et al. 2005; Vahabi and Ghafouri 2009). Today, it is a routine approach to use models to simulate rainfall-runoff, to access flood properties, including timeto-peak discharge. Therefore, the calibration and assessment of models are an inevitable and necessary task. WMS is a conceptual model which consists of different methods, including TR-55 (Technical Release 55), TR-20, SCS, HEC-1, and NFF (National Flood Frequency Regression Equation) (EMRL 1998). A number of studies have been conducted to employ this model for determining the peak flood discharge of different basins. Akbarpour and Sharifi (2005) used GIS (Geographical Information system) to obtain the physiographical characteristics of slope map, soil texture, and runoff curves of Bayeg and Rashtkhar basins, but determined the peak flood discharge of both 


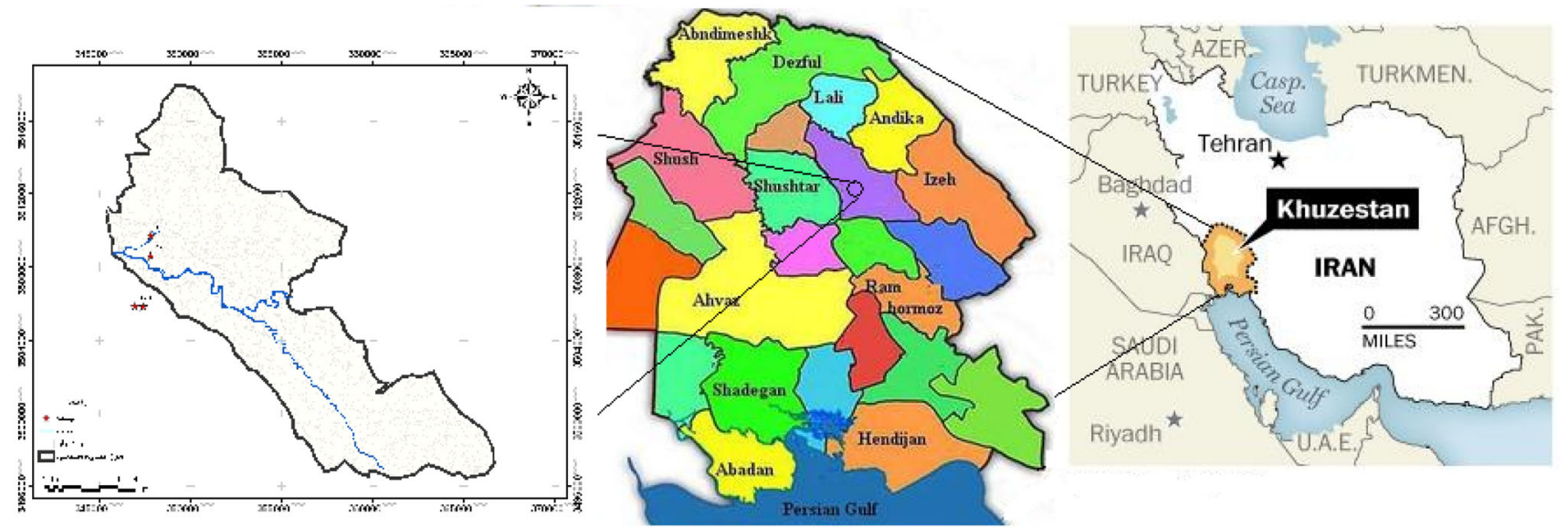

Fig. 1 Location of the studied region in Iran

basins using the WMS model. Based on their studies and sensitivity analysis, soil texture is an influential factor of peak flood discharge.

Benavides et al. (2001) evaluated flood control solutions through combined approaches available in GIS and other hydrologic software and obtained flood plain mapping in Cleakbasin. The obtained results suggested that a combined use of flood estimation techniques can increase the accuracy of estimation in the studied basin.

Dastorani et al. (2010) estimated flood discharge in UK basins with no registered statistics using artificial neural networks and reported satisfactory results. In their study, they expressed that to obtain satisfactory results, it is necessary to adopt a proper approach to identify and classify uniform basins.

Patrick et al. (2002) adopted six different approaches to estimate the mean flood discharge in Ontario, Canada, and compared their results.

Considering the fact that WMS has different methods for determining peak flood discharge, the accurate use of this model requires the investigation of each method, to select the model which best fits the flood data of the studied region. Therefore, this study tends to assess and calibrate the TR-20, TR-55, and HEC-1 methods of the WMS model in a given geographical region in Southwest Iran.

\section{Materials and methods}

\section{Studied region}

Simili Alluvial plain is located in Southwest Iran along the asphalted Ahvaz-Baghmalek road between Baghmalek and Haftgel cities, $70 \mathrm{~km}$ away from the northeast of Haftgel. The plain is surrounded by its mountains and is considered as a flat plain of Khuzestan Province. It lies within $49^{\circ} 21^{\prime \prime}-$ $49^{\circ} 30^{\prime \prime}$ longitude and $31^{\circ} 39^{\prime \prime}-31^{\circ} 44^{\prime \prime}$ latitude. Simili is a plain that stretches from the northwest to the southwest and is surrounded by hilly heights. Its height is almost $563 \mathrm{~m}$ with a general slope from the east-southwest to northwest. Its area is approximately $49 \mathrm{~km}^{2}$. Figure 1 shows the location of the studied plain in Iran and Khuzestan Province.

\section{Physiographic studies}

Basin physiography or in a simpler word, morphology, is a base subject of the hydrology field, and important parameters, such as the area, slope, and time of concentration along with the length gradient of the main stream, will be the main outcomes of this field. The studied basin map (scale: 1:25,000) and WMS model were used to conduct physiographic studies. This study used Arc GIS 9.2 and Arc Hydro Extension to obtain the properties of the studied basin. DEM (Digital Elevation Map) of the National Cartographic Center, NCC, was used for this purpose. The studied region of Simili basin was determined by putting the map sheets (58531se, 58532nw, 58532ne, 5852sw, 58532se, 59532sw, 59532nw, and 5953sw) together and merging them in River Tools. Figure 2 shows the DEM of the studied region, as well as the stream lines of the studied basin. Figure 3 shows the sub-basins of the studied basin, and Table 1 summarizes its features.

\section{Results and discussion}

\section{Estimation of peak flood discharge using SCS method}

Since there was no stream gauge (hydrometric station) in the studied area, the US, Soil Conservation Service 
Fig. 2 DEM map of the studied region

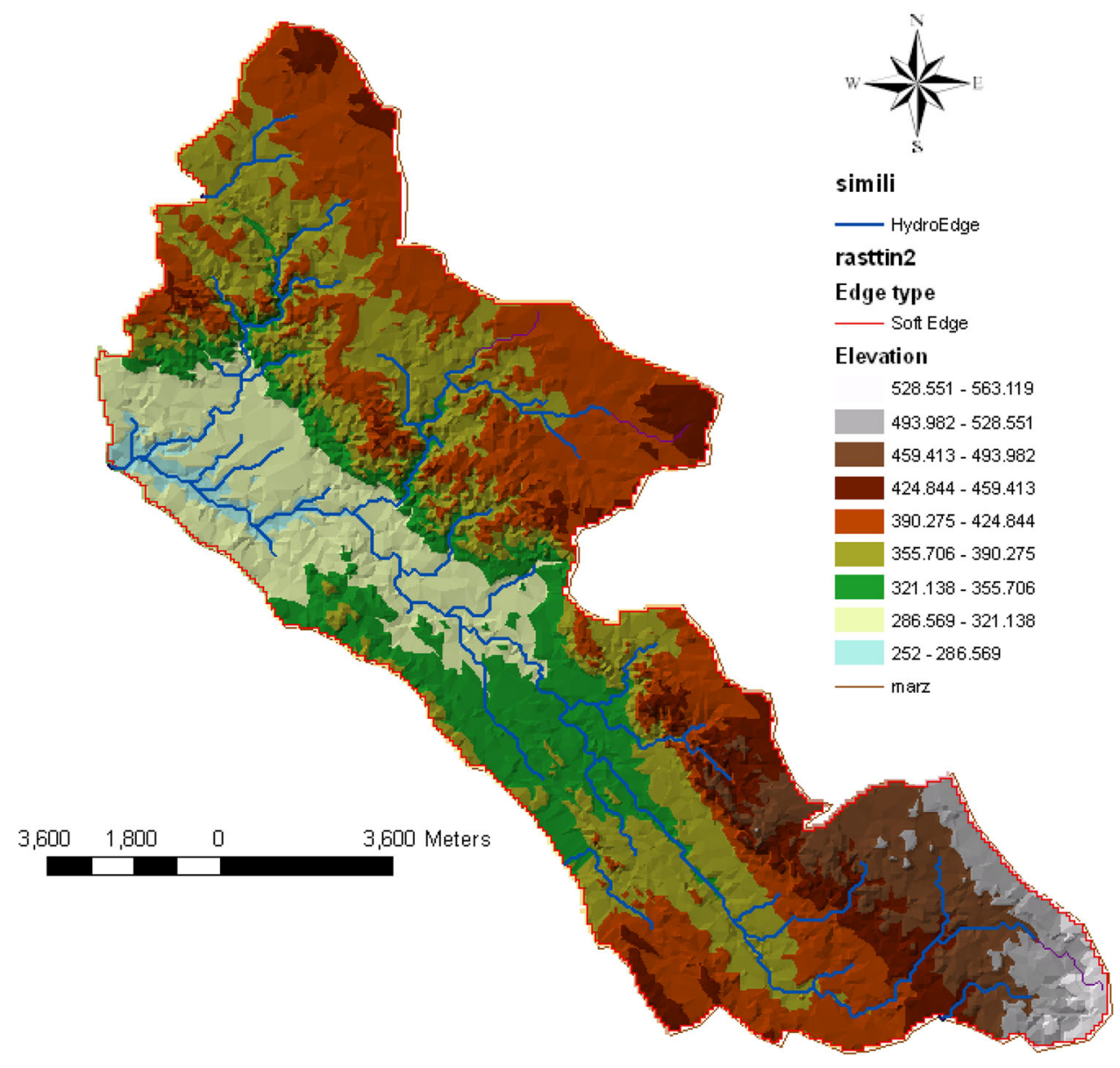

method, SCS was used to extract the unit hydrography (UH) of sub-basins. The concentration time of the basin was derived from the following relation (Hydrologic Engineering Center 1998):

$\mathrm{Tc}=\left(\frac{0.871 L^{3}}{\Delta h}\right)^{0.385}$

where Tc is time of concentration (h), $L$ is the flow length (m), $\Delta h$ is the difference between the minimum and maximum heights of the region.

However, the difference between the minimum and maximum heights of the region is derived from the following relation:

$\Delta h=H_{\max }-H_{\min }$.

To estimate the basin flood using the SCS approach, the following steps were utilized.

\section{Selection of storm duration}

Since the time of concentration of the studied basin is $4.5 \mathrm{~h}$ (less than $6 \mathrm{~h}$ ), the continuity of storm was considered as $6 \mathrm{~h}$.

\section{Storm height}

Given $P(24, T)$ in the studied station, the maximum 6-h precipitation with different return periods, $P(6, t)$, is derived from the following equation:

$P_{(6, T)}=\frac{P_{(24, T)}}{1.48}$.

Since the concentration time of the studied sub-basins is less than $6 \mathrm{~h}$, the storm continuity was considered as $6 \mathrm{~h}$. As mentioned previously, in the SCS method, the minimum storm duration is $6 \mathrm{~h}$ unless the time of concentration of a basin becomes more than $6 \mathrm{~h}$, where the minimum storm duration is considered equal to the time of concentration. Table 2 summarizes the results of 6-h precipitation analysis.

\section{Determination of curve number $(\mathrm{CN})$}

To determine the mean $\mathrm{CN}$ coefficient on the surface of the design basin, the surface geological status of the basin, vegetation, and land applications were studied accurately 
Fig. 3 Sub-basins of the Simili basin

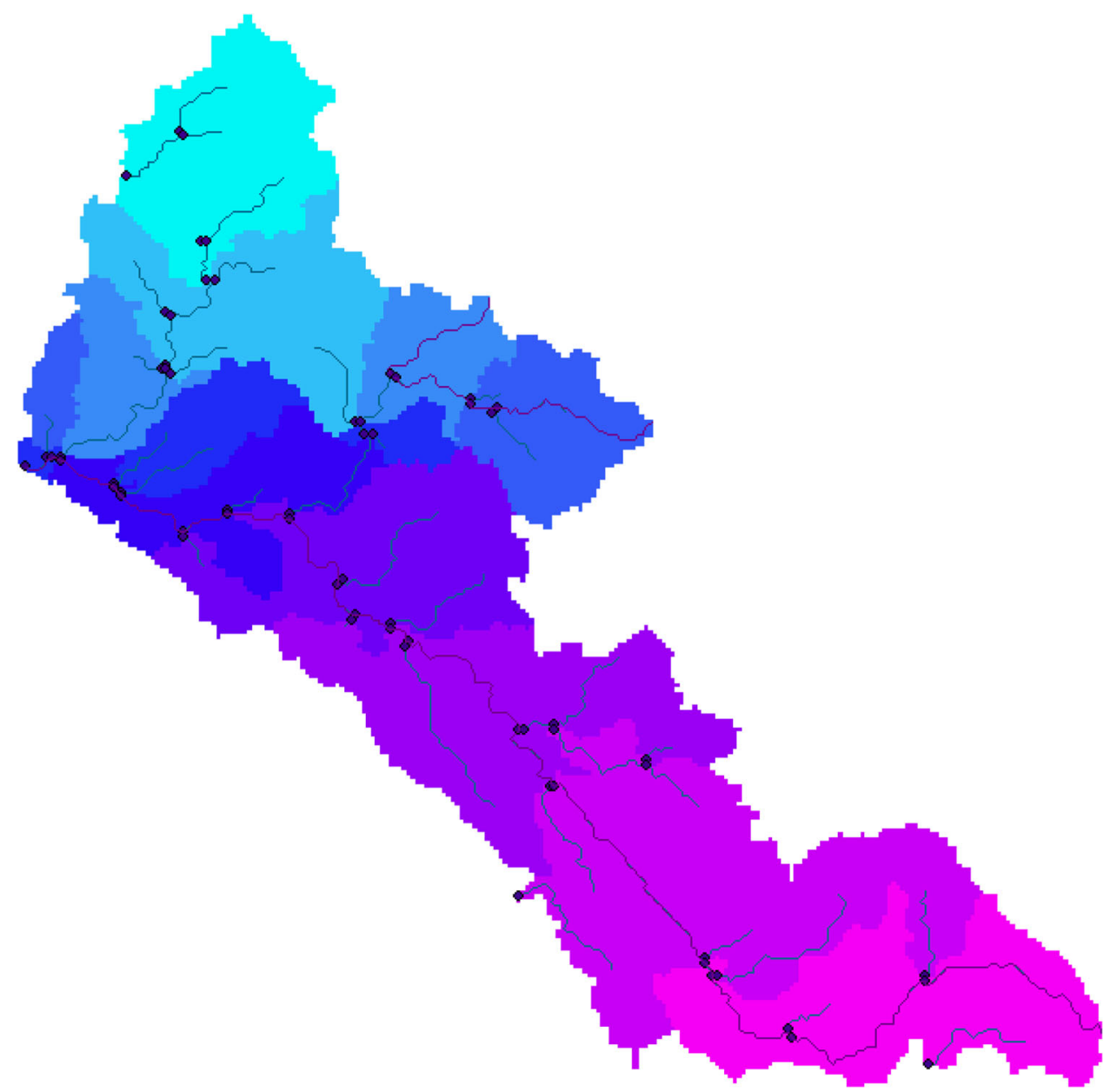

Table 1 Physiographic data of the Simili basin

\begin{tabular}{ll}
\hline UTM & $\begin{array}{l}\text { Latitude: } 3,489,863 \\
\text { Longitude: } 362,572\end{array}$ \\
\hline Area $\left(\mathrm{km}^{2}\right)$ & 46.49 \\
Perimeter $(\mathrm{km})$ & 52.856 \\
Gravelius coefficient & 2.22 \\
Shape factor & 3.14 \\
Main stream length $(\mathrm{km})$ & 16.65 \\
Mean Basin altitude $(\mathrm{m})$ & 263 \\
Slope of the main stream $(\%)$ & 0.98 \\
Time of concentration $(\mathrm{h})$ & Kirpich method: 4.5
\end{tabular}

and the $\mathrm{CN}$ coefficient was estimated. In general, soil hydrologic groups were divided into four subgroups: A, B, $\mathrm{C}$, and $\mathrm{D}$, which represent high permeability, moderate permeability, low permeability, and very low permeability, respectively (Poorhemmat and Sedghi 1999). Geological studies have reported weak vegetation for all four hydrologic groups in accordance with the investigations of the vegetation status of the basin, field visits, and SCS defi- nition. Based on geological studies, permeability, vegetation, mean slope, and hydrologic conditions of basin soil, the $\mathrm{CN}$ value of the Simili basin was estimated to be 85 . Therefore, it can be said that the basin soil lies inside group A from the hydrologic properties point of view. However, all estimations were practiced under average humidity condition.

\section{Estimation of excess rainfall hyetograph}

The basin rainfall-runoff is divided into two sections. Parts of it flows on the surface of the basin (surface runoff), while the remainder is lost as infiltration into the soil or vaporization (Akbarpour and Sharifi 2005; Remizas and Sedghi 1984). Rainfall which flows on the surface of basin and generates flood is called excess rainfall. The amount of excess rainfall for each rainfall is derived from the following relation based on the SCS method. Table 3 shows the results obtained from the calculation:

$S=\frac{25,400}{\mathrm{CN}}-254$ 
Table 2 Design precipitation calculation results in summary

\begin{tabular}{lc}
\hline Return period (year) & Maximum 6-h precipitation $(\mathrm{mm})$ \\
\hline 5 & 54 \\
10 & 66 \\
20 & 77 \\
50 & 92 \\
100 & 103 \\
\hline
\end{tabular}

$Q=\frac{(P-0.2 S)}{(P+0.8 S)}$

where $S$ is the potential maximum retention $(\mathrm{mm}), \mathrm{CN}$ is the runoff curve number, $Q$ is runoff in $\mathrm{mm}$, and $P$ is the rainfall in $\mathrm{mm}$

\section{Calculation of basin unit hydrograph}

Hydrograph and unit hydrograph are typical approaches for determining the peak flood discharge of a basin for different return periods. In this method, flood hydrograph was done based on the physiographic and rainfall properties of the studied basin. The synthetic unit hydrograph is derived from different methods, and the most important of which is the SCS. Figure 4 shows the unit hydrograph of the studied basin.

When the basin unit hydrograph was derived, the design flood hydrograph was calculated based on excess rainfall duration and design rainfall hyetograph. Based on the calculated results, the calculated peak flood rate for a return period of 100 years equals $179 \mathrm{~m}^{3}$. Figure 5 illustrates the design flood hydrograph with a 100 -year return period.

\section{Estimation of peak flood discharge using WMS}

To calculate peak flood discharge using the WMS model, first, digital maps were entered into the software. Following the drawing of stream lines and determination of basin drainage outlet, the basin was closed and its features were extracted. Figure 6 shows the studied basin shape using this model. Here, after extracting the basin parameters, the peak flood discharge was estimated using HEC-1, TR20, and TR55 methods. In this study, the peak flood discharge was calculated by considering a 100 -year return period. Figures 7,8 , and 9 show the results obtained using the aforementioned methods.

\section{Estimation of peak flood discharge using empirical methods (Dicken's method)}

Different studies on Khuzestan watersheds have adopted different empirical equations to calculate the peak flood discharge in basins with no statistics. A series of studies were conducted using 11 stream gauges of the province, where after reconstruction and completion of the station's statistics, a new equation was generated in terms of area and return period, using the correlation between area and a 500-year return period flood of Dicken's equation. This new equation can be applied in Khuzestan Province with a confidence level of $99 \%$ for basins with areas up to $10,000 \mathrm{~km}^{2}$. This new equation was derived as follows (Shahidi and Shahmohammadi 2006):

$Q \mathrm{~m}^{3} / \mathrm{s}=\left(2 / 59 \operatorname{Tr}^{0 / 5235}\right) A_{\mathrm{km}^{2}}^{\left(0 / 692 \mathrm{Tr}^{0 / 0388}\right)}$.

By replacing the area of the Simili basin and a return period of 100 year, the peak flood discharge of the basin was calculated as $691.5 \mathrm{~m}^{3} / \mathrm{s}$.

\section{Discussion and conclusion}

As shown in Table 1, Dicken's empirical method calculated a peak flood discharge of $691.5 \mathrm{~m}^{3} / \mathrm{s}$, while that of SCS was $179 \mathrm{~m}^{3} / \mathrm{s}$, implying a significant difference between the former and the latter. This may be attributed to the $\mathrm{CN}$ calculation errors of SCS. However, the peak flood discharge calculated using TR55 was $407 \mathrm{~m}^{3} / \mathrm{s}$ and its difference with empirical values is less than that of the SCS method.

Table 3 Precipitation hyetograph with a return period of 100 years in the studied region

\begin{tabular}{|c|c|c|c|c|c|}
\hline Rainfall percentage & Percentage from rainfall start & Hours from rainfall start & Rainfall rates $(\mathrm{mm})$ & $Q_{t}(\mathrm{~mm})$ & $\mathrm{d} Q_{\mathrm{t}}(\mathrm{mm})$ \\
\hline 0 & 0 & 0 & 0 & 0 & 0 \\
\hline 2 & 8 & 0.5 & 2.06 & 0 & 0 \\
\hline 8 & 16 & 1 & 8.24 & 0 & 0 \\
\hline 15 & 18 & 1.5 & 15.45 & 0.81995 & 0.81995 \\
\hline 22 & 33 & 2 & 22.66 & 3.20563 & 2.38568 \\
\hline 60 & 42 & 2.5 & 61.8 & 28.5865 & 25.3809 \\
\hline 84 & 66 & 4 & 86.52 & 49.1512 & 5.30694 \\
\hline 96 & 91 & 5.5 & 98.88 & 60.0054 & 3.64972 \\
\hline 100 & 100 & 6 & 103 & 63.683 & 3.67762 \\
\hline
\end{tabular}




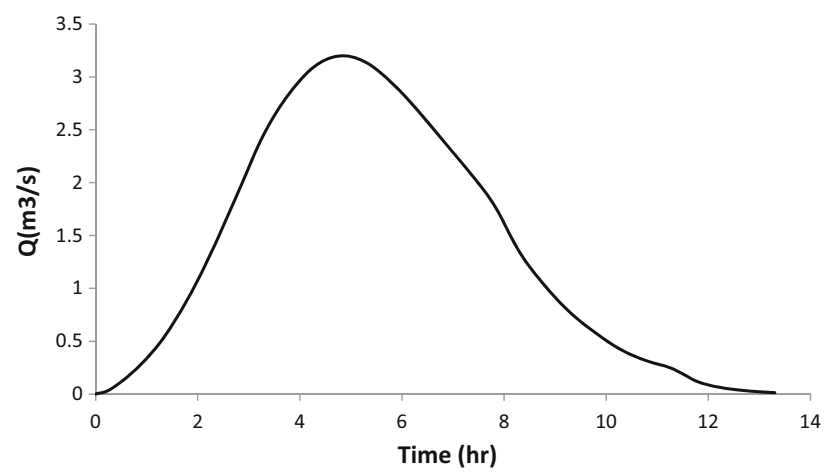

Fig. 4 Unit hydrograph of the studied basin

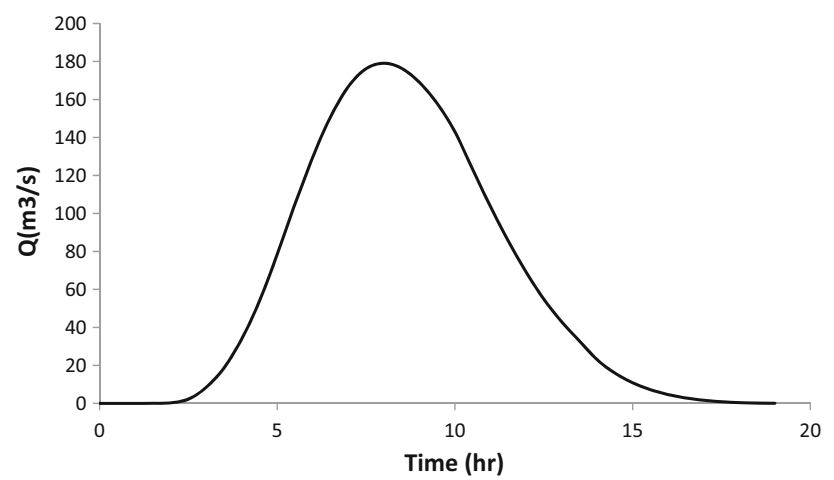

Fig. 5 Flood hydrograph with a 100-year return period provided by SCS

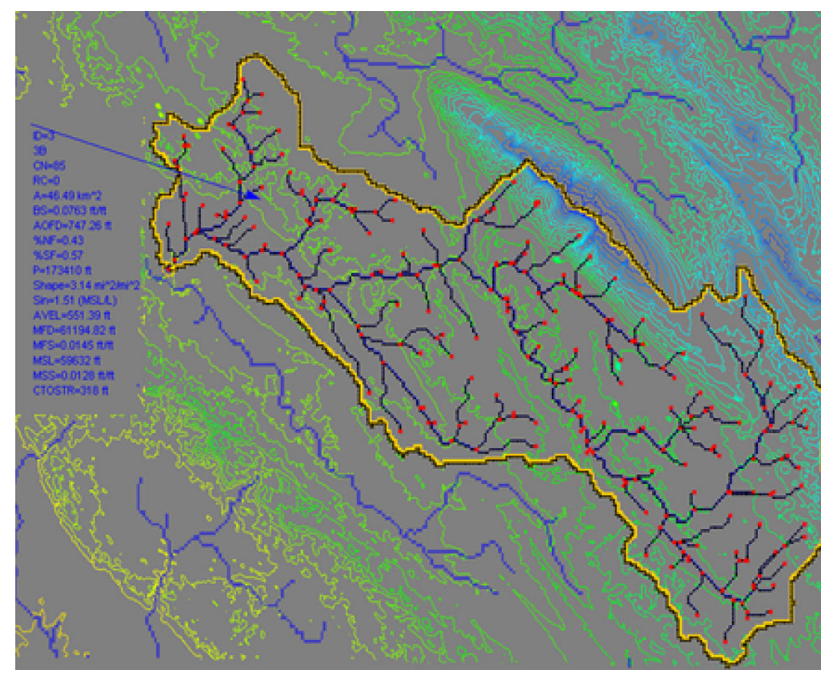

Fig. 6 Simili basin

The peak flood discharge derived from TR20 was $107 \mathrm{~m}^{3} / \mathrm{s}$, which is significantly different from the values derived from other approaches. In addition, the peak flood discharge derived from the HEC-1 method was $381 \mathrm{~m}^{3} / \mathrm{s}$, which is lower than that calculated using Dicken's empirical method. It seems that among the different methods used for determining the peak flood discharge of Khuzestan

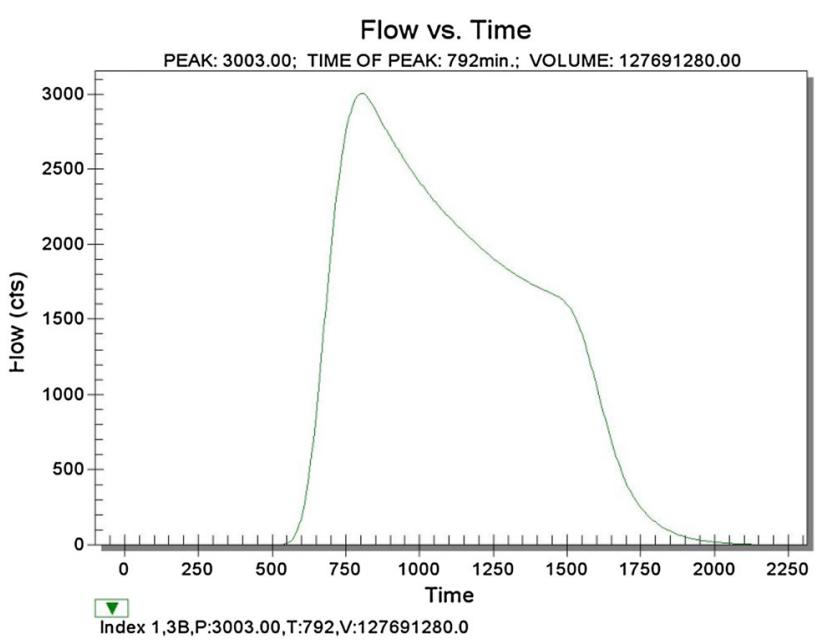

Fig. 7 100-year flood discharge hydrograph estimation using TR20

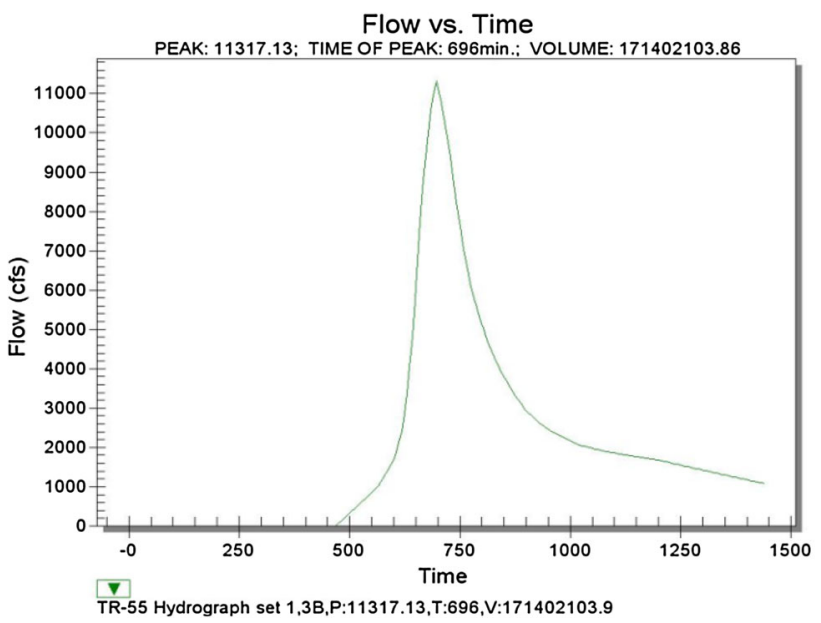

Fig. 8 100-year flood discharge hydrograph estimation using TR55

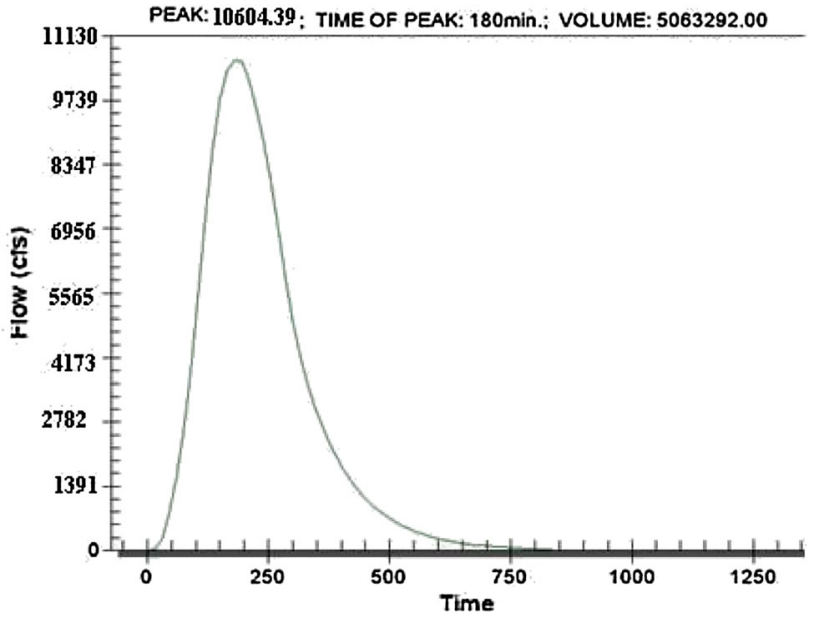

Fig. 9 100-year flood discharge hydrograph estimation using HEC-1 basins, the TR55 method of the WMS model offered values that are closer to the real values. Among the different methods of the WMS model, TR55-HEC-1 and TR20 
methods had the highest accuracy in Southwest Iran, respectively.

There are various factors involved in the flowing of runoff and flooding, including intensity of rainfall, watershed slope, soil infiltrability, topographic conditions, topographic features, vegetation, and soil saturation (Thomas, 1968; Eard 1975). Riggs (1973), showed that watershed area could be the most important factor in runoff discharge, whereas the current study indicated that the adoption of the method for calculating the peak discharge of the hydrograph, even in the same watershed, could yield very different results. In addition to the peak discharge, the time of peak discharge and volume of instantaneous peak discharge will vary by selecting different methods. There are areas in the northern part of the Simili watershed suitable for farming. Moreover, Hansson et al. (2008) found that natural disasters, such as floodwater runoff, initially affect the local agriculture. Hence, simulation and modeling of floodwater runoff and modeling the floodwater are among the key parameters in floodwater management of the region. The TR-55 method is employed for watersheds smaller than 25 square miles, concentration time of shorter than $10 \mathrm{~h}$, rainfall of less than 50 inches, and rainfall duration of shorter than $24 \mathrm{~h}$. All these factors apply to the Simili watershed. Therefore, the greater accuracy of the results from this method than those from Dickens' empirical model may be because the TR-55 model meets all the required conditions. With respect to floodwater volume also, considering the maximum flood discharge estimated in the empirical method, the floodwater volume estimated in the TR-55 method is closer to the actual values, because it estimates the maximum floodwater volume. Following the TR-55 method, the HEC-1, TR-20, and SCS methods rank second to fourth, as they estimate floodwater volumes of 5.06, 4.58, and 3.97 million cubic meters, respectively. Since the rainfall duration considered for the Simili watershed is $6 \mathrm{~h}$, and the concentration time calculated based on morphological features of the watershed was $4.5 \mathrm{~h}$, the time for the hydrograph peak discharge should be longer than the concentration time. According to Table 4, the time for hydrograph peak discharge calculated using HEC-1 is $3 \mathrm{~h}$, which is less than the time of concentration for the watershed. Hence, it cannot be an accurate value. This becomes clearer by considering the estimated floodwater volume that indicates that a large volume of runoff is generated within a short time; since the Simili watershed is rectangular and the main channel in the watershed has a low slope, we expect the base time of the flood hydrograph to be longer that that derived from the HEC-1 method. This could be due to the rainfall distribution pattern considered in HEC-1, which is the same distribution pattern in SCS for rainfall duration of 6 h. In their studies, Modarres and Sarhadi (2010) found that the adoption of a single pattern of rainfall distribution could
Table 4 Flood discharge properties using different methods

\begin{tabular}{llll}
\hline Method & $\begin{array}{l}\text { Peak flow } \\
\left(\mathrm{m}^{3} / \mathrm{s}\right)\end{array}$ & $\begin{array}{l}\text { Floodwater volume } \\
(\mathrm{MCM})\end{array}$ & $\begin{array}{l}\text { Time of } \\
\text { peak }\end{array}$ \\
\hline $\begin{array}{l}\text { Dicken's Empirical } \\
\text { Method }\end{array}$ & 691.5 & - & - \\
SCS & 179 & 3.97 & 480 \\
TR-55 & 407 & 6.15 & 696 \\
TR-20 & 107 & 4.58 & 792 \\
HEC-1 & 381 & 5.06 & 180 \\
\hline
\end{tabular}

not provide acceptable results from simulations of maximum instantaneous discharge and hydrograph. Features related to rainfall are among the most important factors in hydrograph simulation. Due to the insufficient statistics at the hydrometric stations in the region, however, the distribution of rainfall in the region cannot be incorporated into the model. The peak discharge obtained from SCS was $25 \%$ less than that obtained from Dicken's empirical method. Moreover, the flood volume calculated by this method is lower as compared to those in other methods. Studies in Iran have demonstrated that the SCS method delivers accurate results for concentration time of down to $6 \mathrm{~h}$, but not for concentration time of less than that. This could be due to the insensitivity of SCS to low rainfall depths. Hence, concentration time of less than $6 \mathrm{~h}$ should be modified (Alizadeh 2006). There are two procedures for using SCS in calculating peak discharge in small watersheds: (1) coefficients or graphs that modify peak discharge for small watersheds and (2) runoff is obtained for concentration time of $6 \mathrm{~h}$, and then, the unit hydrograph is used (Mc Cuen 1989). The same logic is used in TR-55. The TR-20 calculated the minimum discharge (15\% of the value obtained from Dickens' empirical method) with the maximum time to reach the peak discharge (about $13 \mathrm{~h}$ ). This method involves using the unit hydrograph of the US Army Corps Engineers (2000). This model is based on the average unit hydrograph obtained from rainfall-runoff data for small agricultural watersheds in the United States, and the unit hydrograph of the watershed is calculated through using the dimensionless hydrograph in TR-20 (Chow et al. 1988; Nourani et al. 2009). Since the watershed lag time in this method is entered into the model as the main parameter, the results may drift apart from actual values in the case, the watershed concentration time is not calculated well. Moreover, the reference unit hydrograph in this method is that for small agricultural watershed in the United States. Therefore, differences in climatic conditions in generating the reference hydrographs in this method caused results obtained from using it in southwest of Iran to be far from the actual values. In a study across northeast of Iran, Lalozaee et al. (2013) found that HEC-1 provided more accurate results than TR-20.

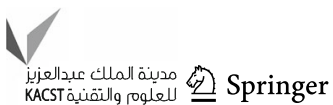




\section{Conclusions}

According to the results, it can be argued that, among the different methods used for estimating flood discharge in the southwest of Iran, the results obtained from the WMS model are lower than the empirical method. In fact, all the methods in the WMS model require calibration in the study region. In the small watersheds in the southwest of Iran, the TR-55 model yields better results than other methods, because the conditions required from using this model are satisfied. Moreover, the results obtained from this method can be pushed closer to the actual values if the watershed concentration time is calculated more accurately. Results of the present research showed that the HEC-1 model did not provide an accurate estimate of floodwater volume. Given the high sensitivity of this method to rainfall distribution across the region, an analysis of rainfall across the region is required to obtain desirable results and the rainfall distribution and its time distribution should be pushed close to the corresponding values in the region. Furthermore, the results of the present study indicated that the poor accuracy of SCS resulted from the fact that it is used for large watersheds with concentration times of longer than $6 \mathrm{~h}$. It was revealed that the adoption of this method requires that the coefficients for conversion of peak discharge to peak discharge of small watersheds should be determined. Results indicated that the inaccuracy of TR-20 was due to different climatic conditions in the extraction of unit hydrographs compared to the climatic conditions across southwest of Iran.

Acknowledgments The authors of this paper would like to express their sincerest gratitude to the Mohaghegh Ardabili University of Ardabil, Iran who made this research possible and for the partial funding of this research.

\section{Compliance with ethical standards}

Conflict of interest The authors declare that they have no conflict of interest.

Open Access This article is distributed under the terms of the Creative Commons Attribution 4.0 International License (http:// creativecommons.org/licenses/by/4.0/), which permits unrestricted use, distribution, and reproduction in any medium, provided you give appropriate credit to the original author(s) and the source, provide a link to the Creative Commons license, and indicate if changes were made.

\section{References}

Alizadeh A (2006) Principles of Applied Hydrology, 20th edn. Emam Reza University Publications, Mashhad, pp 808 (in persian)

Alkbarpour A, Sharifi, MB (2005) Investigation and application of WMS model in river engineering; case study: Bayegh and Rashtkhat basins in Khorasan Province'; 5th Iranian Hydraulic
Conference, Shahid Bahonar University, Kerman, p 8 (in persian)

Benavides JA, Pieruszewski B, Bedient PB, Kirsch B (2001) Analyzing flood control alternatives for the clear cleak watershed in a geographic information systems framework. In: Proceedings of the environmental and Water Resources Institute's World Water and Environmental Resources Congress. Orlando, Floria, pp 16

Bhadra A, Panigrahy N, Singh R, Raghuwanshi NS, Mal BC, Tripathi MP (2008) Development of a geomorphological instantaneous unit hydrograph model for scantily gauged watersheds. J Environ Model Softw 23:1013-1025

Chow VT, Maidment DR, Mays LW (1988) A general theory of the unit hydrograph theory. J Geophys Res 64:241-256

Dastorani MT, Talebi A, Dastorani M (2010) Using neural networks to predict run off from ungauged catchments. Asian J Appl Sci 3(6):399-410

Eard LR (1975) Hydrologic frequency analysis In: Hydro engineering method for water resources development logic, US. Army corps of engineers, pp 176

Environmental Modeling Research Laboratory (EMRL) (1998) Watershed modeling system (WMS) reference manual and tutorial. BrighamYoung University, Provo

Hansson K, Danielson M, Ekenberg L (2008) A framework for evaluation of flood management strategies. J Environ Manag 86(3):465-480

Hydrologic Engineering Center (1998) HEC-1, Flood Hydrograph Package, User's Manual, Version 4.1, US Army Corps of Engineers, Davis, 95616, CA

Lalozaee A, Bahreini F, Dahmardeh M, Akbarpour A, Moghaddamnia AR (2013) Efficiency comparison HEC-1 and TR-20 methods in flood hydrograph simulation. Tech J Eng Appl Sci. 3-15/1719-1729

Lopez V, Napolitano F, Russo F (2005) Calibration of a rainfallrunoff model using radar and rain gauge data. J Adv Geosci 2:41-46

Mc Cuen RH (1989) Hydrologic analysis and design. Prentice-Hall Inc., Totowa. ISBN 0-13-447954-8

Modarres R, Sarhadi A (2010) Statistically-based regionalization of rainfall climates of Iran. Global Planet Change 75(2011):67-75

Nourani V, Singh VP, Delafrouz H (2009) Three geomorphological rainfall-runoff models based on the linear reservoir concept. J Catena 76:206-214

Patrick LG, Donald HB, Juraj MC (2002) A comparison of index flood estimation procedure's for ungauged catchments. Can J Civ Eng 29(5):734-741

Poorhemmat J, Sedghi J. (1999). Assessment and calibration of HEC1 model in sub-basins of Bazeft, karoun, The 1st regional meeting of water balance, Ahvaz, Iran, pp 133-1473 (in persian)

Remizas J, Sedghi H . (1984) principles of hydrology Engineering, Shahid Chamran University, Ahvaz (in persian)

Riggs HC (1973) Regional analyses of stream flow characteristics: techniques of water-resources investigations of the US Geological Survey, Book 4, Chapter B3, 15. http://pubs.usgs.gov/twri/ twri4b3/. Accessed 16 June 2010

Shahidi A, Shahmohammadi HZ (2006) Calibration of empirical relations for estimating peak flood discharge in sub-basins of Haroon and Zohre, Khuzestan", the 1st regional meeting of exploiting water resources of Karkerden and Zaianderood basins, Shahrkor University (in persian)

Thomas WO, Benson MA (1968) Uniform flood frequency estimating methods for federal agencies. Water Resources Geol 4:891-980

United States Army Corps of Engineers, Hydrologic Engineering Center (USACE-HEC) (2000) Hydrologic modeling system HEC-HMS technical reference manual. Davis

USBR (1998) Flood hydrology manual. GPO, Washington 
Vahabi J, Ghafouri M (2009) Determination of runoff threshold using rainfall simulator in the southern Alborz range Foothill-Iran. Res J Environ Sci 3:193-201
Yonatan B, Tamir G, Judith L, Efrat M (2009) Rainfall-runoff modeling in a small hyper-arid catchment. J Hydrol 373:204-217 